\title{
ArTiCles
}

http://dx.doi.org/10.15762/ZH.2018.19

MONIKA TOMKIEWICZ

(Institute of National Remembrance

Branch of the Commission for the Prosecution of Crimes against the Polish Nation)

\section{Childcare Centre for Polish Boys in Wejherowo DURING THE GERMAN OCCUPATION*}

Key words: Neustadt, German childcare centres for Polish children, orphanages, territories incorporated into the Third Reich, everyday life in Gdańsk Pomerania during the German occupation

On 9 September 1939 at about 10 a.m. Wejherowo was taken over by German soldiers from the $2017^{\text {th }}$ Infantry Division of Karl von Tiedemann (the division consisted of 160 officers and 606 non-commissioned officers), the $32^{\text {nd }}$ Regiment Grenzwache von Bothmer, the Battalion of SS-Heimwehr Danzig $^{1}$ of Mayor von Rittberg and the $5^{\text {th }}$ Regiment of the Cavalry of Diener. In administrative terms, Wejherowo Land became part of the Reich Province Gdańsk-West Prussia, while the town received the name of Neustadt (Westpreussen). German institutions quickly replaced Polish cultural and educational bodies. The German occupation authorities skilfully took over farm

\footnotetext{
* The text was created on the basis of the materials from the investigation of the Branch of the Commission for the Prosecution of Crimes against the Polish Nation in Gdańsk. The first correspondence concerning this issue was received by the former District Commission for the Research of Hitler's Crimes in Gdańsk in May 1990. Since 1990 the Commission had conducted the examinations of the case. The investigation started on 25 January 1997 and suspended on 29 January 1999 when the institution was closed down. On 9 November 2000 the prosecutor started the investigation again; on 26 September 2002 the prosecutor decided to discontinue the investigation.

${ }^{1}$ SS-Heimwehr Danzig - The German military formation of Waffen-SS operating in the years 1939-1940. It consisted of members of Battalion III of the $4^{\text {th }}$ Regiment SS-Totenkopf "Ostmark", which were illegally transported to Gdańsk and about 1500 volunteers from Gdańsk. SS-Heimwehr Danzig became part of the Brigade of Gen. Friedrich Eberhardt. On 1 September 1939 it participated in the attack on the building of the Polish Post Office in Gdańsk; later in two unsuccessful attacks on the Military Transit Repository in Westerplatte. Members of this unit also took part in mass executions in Szpęgawski Forest, see: Rolf Michaelis, SS-Heimwehr Danzig 1939, Warszawa 2003, pp. 7-9; P. Krauss, Damals. Heimwehr Danzig. Erinnerungen und Begegnungen, Coburg 1982, without page numbers; Jan DanILuk, SS w Gdańsku, Gdańsk 2013, pp. 97-98.
} 
buildings, which before the war had belonged to the National Social Care Provider at 279 Adolf-Hitler-Straße (previously and now 279 Jana Sobieskiego Street) and accommodated there their military units.

The buildings were constructed in the years 1881-1883 and were destined to serve as a psychiatric hospital, which could offer the treatment for about 400 patients from the province of West Prussia. The building complex included a dozen edifices situated on the way from Wejherowo to Bolszewo. Twentyfive morgens of the municipal forest and 160 morgens of private land were donated for this purpose. It was second modern psychiatric hospital in the province (after the hospital in Świecie). In the years 1920-1939 it became part of the newly created National Social Care Provider. Its patients were mainly Poles along with Russian and German prisoners of war. On 15 September 1933 the hospital was finally liquidated, and the sick were transported to Psychiatric Hospitals in Świecie and Kocborowo ${ }^{2}$. On 20 September 1933 five buildings were assigned to accommodate soldiers of the Sea Battalion (in 1937 converted into the $1^{\text {st }}$ Sea Rifle Battalion). In one of the edifices there was a primary school for the deaf-mute. After WWI finished, when schools for deaf children in Człuchów and Malbork were situated beyond the boundaries of the Polish state, it was necessary to set up an institution like this for children from the Pomeranian District. The National Authority Office [Starostwo Krajowe] in Toruń on 1 September 1921 decided to create a school for deaf children under the name of the Pomeranian National Facility for the Deaf-Mute. It was to be seated in Wejherowo in several buildings, formerly used by the psychiatric hospital, assigned now to this purpose. The organizer and the first head of the institution was Leonard Retzlaff. The school was located in building no. 8, while dormitories in buildings no. 10 and 12. In the first school year of the institution there were 10 deaf children, including 40 girls and 60 boys who were taught by 12 teachers ${ }^{3}$. From 1923 in Wejherowo, near the barracks in Jana Sobieskiego Street, in the vicinity of the buildings of the Pomeranian Na-

${ }^{2}$ In the interwar period in the national Psychiatric Hospital in Kocborowo stayed about 1200 patients - females and males. The first selection of sick people destined to be killed as part of the T4 action took place in September 1939. Apart from murders in Szpęgawski Forest, patients were also killed in the mortuary of the hospital. In the autumn of 1939 patients from the liquidated psychiatric hospital in Świecie were brought to Kocborowo. Some of them were also killed in Szpegawski Forest. Supposedly, some patients were transported to Skarszewy and murdered there. See: Oddziałowa Komisja Ścigania Zbrodni przeciwko Narodowi Polskiemu w Gdańsku [the Branch of the Commission for the Prosecution of Crimes against the Polish Nation in Gdańsk] (further cit. OK.Gd.), sygn. Ko 187/73, postępowanie sprawdzające w sprawie zbrodni popełnionych na pacjentach szpitala psychiatrycznego w Kocborowie.

${ }^{3}$ Historia Ośrodka Szkolno-Wychowawczego $n r 2$ dla Głuchych im. J. Siestrzyńskiego w Wejherowie, Wejherowo 1991, pp. 7-17. 
tional Facility for the Deaf-Mute there was seated the Educational Facility for Siberian Children ${ }^{4}$.

In the 1930s the Educational Facility for Siberian Children and the Pomeranian National Facility for the Deaf-Mute were converted into the National Social Care Facility. It consisted of the Primary School for Deaf Children and the Educational Facility. Additionally, in 1933 the children, staff and the directors of the Pomeranian Youth Detention Centre and the Centre for the Poor in Chojnice were moved to the Wejherowo institution ${ }^{5}$. In September 1939 deafmute children stayed on holiday trips away from the centre, and in the buildings there were only residents of the Youth Detention Centre. Polish teachers, e.g. Józef Kotewicz and Józef Kamiński, both reserve officers, were called up to the active military service in the units of the $1^{\text {st }}$ Rifle Regiment in Wejherowo ${ }^{6}$.

At the beginning of the German occupation in the territories incorporated into the Third Reich all Polish orphanages and educational facilities were taken over by the German authorities. It was in accordance with the guidelines included in the study prepared by the Political-Racial Bureau in November 1939 titled: "The issue of the treatment of the population of the formerly Polish territories from the racial-political point of view", in which it was recommended that children who "came from the German predecessor" be excluded from the displacement as they should be brought up in appropriate educational facilities following the old Potsdam model of the House of Orphans in the conditions of the military discipline or in German families ${ }^{7}$.

The large-scale policy of the German authorities aiming at the elimination of any traces of the Polish culture in Pomerania consisted also in carrying out the racial selection of children from various backgrounds with particular emphasis on the children staying in Polish social care facilities and foster families. In all educational and social care facilities (e.g. in Wejherowo, Kamień Pomorski, Kietrz and Grodkowo) the Polish personnel was replaced with the Ger-

\footnotetext{
${ }^{4}$ Regina Osowicka, Matki mdlały z rozpaczy, sieroty z głodu jadły śnieg. Odyseja „polskich dzieci syberyjskich" przez Japonię do Wejherowa, Dziennik Bałtycki, no. 321 of 2 December 1994, p. 7.

${ }^{5}$ Henryk Porożyński, Zakład Poprawczy w Chojnicach w latach 1885-1985, Słupsk 1991, pp. $19-28$.

${ }^{6}$ Among other people employed in the school in Wejherowo one should mention: Teofil Lisakowski, Edmund Fenski, Józef Idzikowski, Brunon Mejer, Jaa Bieńkowski, Jan Maciejewski, Rev. Józef Bartel, Aleksa Kolasińska, Bronisława Wryczanka, Maria Tomaszewska, Elżbieta Szuttówna, Franciszek Szank, see: Józef Kotewicz, Pięćdziesięciolecie ośrodka szkolno-wychowawczego $n r 2$ dla głuchych $w$ Wejherowie (Biblioteka Muzeum Piśmiennictwa i Muzyki Kaszubsko-Pomorskiej w Wejherowie), Wejherowo 1983, p. 66.

${ }^{7}$ Roman Z. Hrabar, Janczarowie XX wieku, Katowice 1983, pp. 18-19; Włodzimierz JAstrzęBski, Jan Sziling, Okupacja hitlerowska na Pomorzu Gdańskim w latach 1939-1945, Gdańsk 1979, pp. 167-171.
} 
man staff and the prohibition to use the Polish language was introduced. Many children stayed in such facilities before the outbreak of the war, but it should be underlined that residents of such facilities were often children taken away from their parents who had refused to sign the German People's List ${ }^{8}$; taken away from foster families or brought up by relatives; children of killed partisans or hostages; children from culturally mixed marriages, where the custody was given to the German family. Prior to being subjected to the process of Germanization, very often children underwent health, psychological and racial tests. Intelligence and personality features were also significant. The age of children who could stay in educational facilities was from 8 to 10 years of age since it was only in this period of life that the appropriate completion of the Germanization process was feasible? .

In the Wejherowo facility as early as September 1939 the German administration dissolved all the employment contracts with Polish teachers, pedagogues and auxiliary personnel employed in the pre-war Primary School for Deaf-Mute. Children who resided in the institution and the equipment used for educational purposes were transported to a similar facility in Bydgoszcz. The library of the school (situated in building no. 8) was heavily affected as about 500 Polish books were burnt. The most valuable part of the book collection was hidden in the attic of the block no. 4 by the Polish teachers of the schools: Konstanty Willma, Jan Nacmer and Teodor Smagała ${ }^{10}$.

From November 1939 in some of the buildings used before the war by the Care Centre ${ }^{11}$ two divisions of Wehrmacht Wehrkreis XX were stationed.

${ }^{8}$ On 4 March 1941 the act of the German People's List [Deutsche Volksliste] was announced in the territory of occupied Poland, see: Karol Marian Pospieszalski, Niemiecka Lista Narodowa w „Kraju Warty” (Documenta Occupationis Teutonicae, t. 4), Poznań 1949; Ryszard KaCZMAReK; Niemiecka polityka narodowościowa na Górnym Ślasku (1939-1945), Pamięć i Sprawiedliwość, 2004, nr 2 (6), pp. 115-138.

${ }^{9}$ Edward Leszczyński, Sonderbehandlung. Zbrodnia na polskich dzieciach, Wrocław 2014, pp. 30-34; Konrad Ciechanowski, Okupacyjne losy polskich dzieci i młodzieży na Pomorzu Gdańskim, [in:] Dzieci i młodzież w latach drugiej wojny światowej, ed. Czesław PiLICHowski, Warszawa 1982, pp. 289-298; Józef Wnuk, Helena Radomska-Strzemecka, Dzieci polskie oskarżają 1939-1945, Warszawa 1961, pp. 7-12; Historia Wejherowa, ed. Józef BonzYszKowski, Wejherowo 1998, p. 384; Roman Z. HrabaR, Hitlerowski rabunek dzieci polskich. Uprowadzanie i germanizowanie dzieci polskich w latach 1939-1945, Katowice 1960, p. 1.

${ }^{10}$ According to the account given by the teacher Konstanty Willma, the building was burnt in 1945 along with all the books. Zygmunt Milczewski, Wejherowo i powiat morski wrzesien 1939 - maj 1945 (kronika), Gdańsk 1991, p. 31; Ziemia wejherowska, Gdańsk 1980, p. 182; J. KoTEWICZ, op.cit., p. 67.

${ }^{11}$ OK.Gd., sygn. S 6/00/Zn, śledztwo w sprawie dyskryminacji dzieci polskich w zakładzie wychowawczym $\mathrm{w}$ Wejherowie $\mathrm{w}$ okresie okupacji hitlerowskiej, protokół przesłuchania świadka Antoniego Konkel, 11 IV 1994 r., t. 1, pp. 81-83; sygn. S 77/10/Zn, śledztwo w sprawie zastrzelenia w dniu 10 IX 1939 r. na dziedzińcu więzienia w Wejherowie polskich jeńców wo- 
From 1 September 1939 the Wejherowo barracks at 279 Adolf-Hitler-Straße were taken over by the $62^{\text {nd }}$ artillery unit (Artillerie-Ersatz-Abteilung 62). The adjustment of the land and the buildings for the military needs was very labour-consuming. As the winter was approaching, it was necessary to find places to garage cars and assault guns. The technical condition of the post-hospital buildings was bad. In two of the rooms where soldiers were accommodated there existed a risk of the ceiling falling down. The buildings needed refitting. The former kitchen was obsolete and not sufficiently equipped to cater for the needs of so many soldiers ${ }^{12}$.

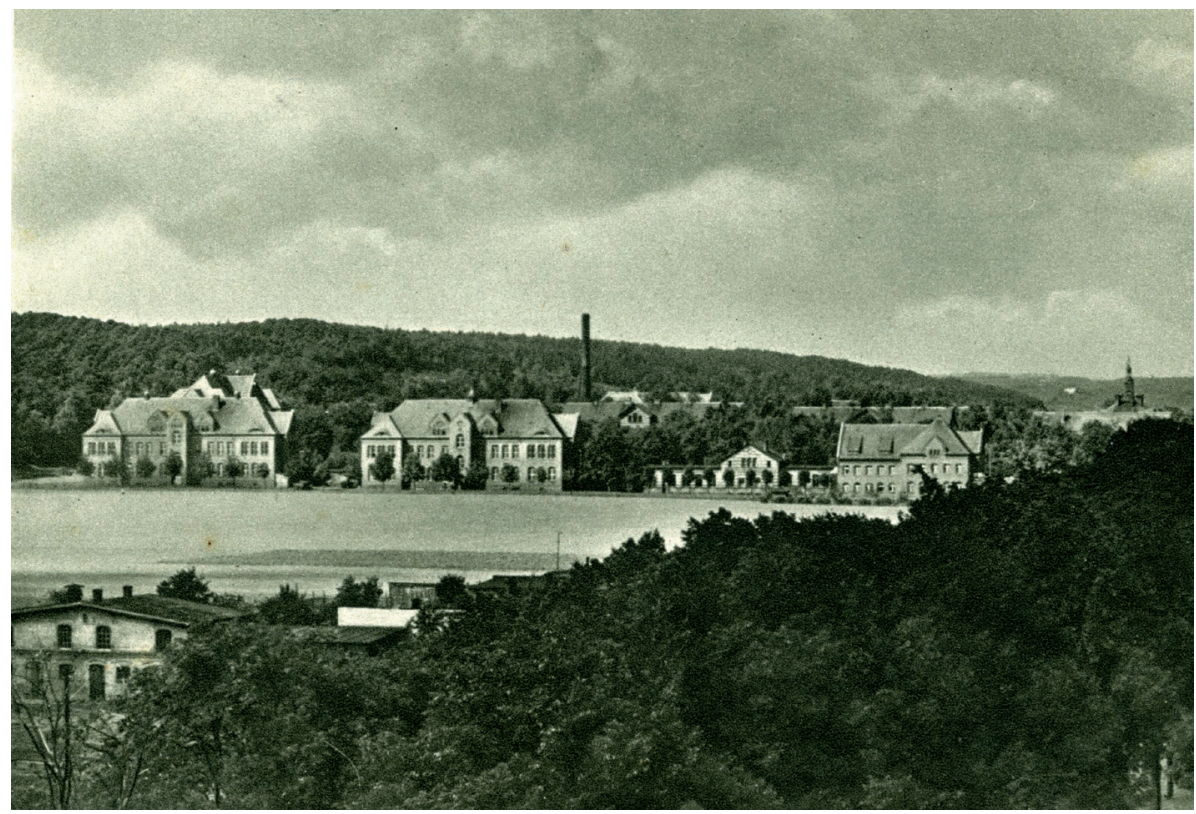

The complex of buildings where the Educational Facility for Boys in Wejherowo was situated in the years 1939-1943, now the seat of the School-Educational Centre no. 1 under the name of Janusz Korczak, the Museum of Writing and Kashubian-Pomeranian Music in Wejherowo

In the complex of the buildings in Adolf-Hitler-Straße only blocks no. 2 and 4 were not taken over by the army along with the farm belonging to the facility. In both buildings new institutions were seated: in the two-storey

jennych Aleksandra Wikieła i Józefa Nowaczyka przez funkcjonariuszy gdańskiego gestapo, Pismo Krajowego Urzędu Kryminalnego Badenia-Wirtembergia, t. 2, pp. 290-294; Archiwum Państwowe w Gdyni [The National Archives in Gdynia], Krajowe Zakłady Opieki Społecznej w Wejherowie 1920-1939, zespół 223.

${ }^{12}$ Staatsanwaltschaft bei dem Landgericht Hannover, Proces Kurta Eimanna i Georga Erbrechta, sygn. 2 Js 614/62, 9 I 1963 r., pp. 6256; Bundesarchiv Ludwigsburg, sygn. B 162/7786 Sonderheft Piaśnica. 
edifice - the Educational Facility for Polish Boys (Erziehungsanstalt Neustadt Westpreussen), whilst in the pavilion on the ground floor - the Youth Detention Centre for Boys from Gdańsk (Gauerziehungsheim für Jungen Neustadt Westpreussen). In the two-storey edifice, on the ground floor, there were a kitchen, a canteen, a chancellery, office rooms and classrooms. On the first floor there were bedrooms for boys and bathrooms. The barracks were separated from the facility with a chain link fence.

In the years 1939-1943 Polish and German boys (the youth from Gdańsk) stayed in the Wejherowo facilities in separate buildings. They were aged between 4 and 21 - born between 1918 and 1935. They came from the territories of the former Pomeranian voivodeship, mainly Bydgoszcz, Grudziądz, Toruń, Gdynia, Starogard Gdański, Golub, Dobrzyń and Kartuzy. Polish children were sent to the Educational Facility in Wejherowo by the German police authorities: the Municipal Office for Affairs of Minors (Stadtjugendamt), the County Office for Affairs of Minors (Kreisjugendamt), the Bureau of Social Care (Fürsorgenamt), the District Commissary (Amtskommissar). Detailed information about boys residing in the facility were included in the "Record Book" ("Aufnahmebuch"). Entries to the book were written in Polish and German. The book included the following information: the first name, the surname, the place of birth and the county, the date of birth, marital status, denomination, profession and the place of residence of the parents, the name of the legal guardian, the name of the institution sending the boy to the educational facility and the reason of the boy's detention, the leaving date, the reason for leaving, kind of dismissal and remarks. One may notice that in the case of older boys comments were made in the Polish language, and later continued in German. Thus, it may be concluded that at least some boys who had stayed in the facility before the war remained there after the Germans marched into Wejherowo. The earliest admission date of a boy to the facility was 26 February 1936 (Zygfryd Kotlecki, born 14 May 1918 in Toruń) sent to the Wejherowo institution by the City Government of Toruń). The last entry in Polish was made on 19 August 1939 and concerns Marian Matuszewski, born on 19 March 1923 . The first entry made by the German administration referred to Gerard Sroczyński (born 6 May 1924 in Grudziądz) and came from 13 March 1940. The last admission to the facility marked with the entry number 2849 took place on 28 October 1943 and concerned Franciszek Bębenek, born on 12 June 1926 in Elbląg ${ }^{13}$.

${ }^{13}$ Aufnahmebuch Erziehungsanstalt Neustadt, without page numbers, nr 1-2849, OK.Gd., sygn. S 6/00/Zn, załącznik do akt nr 1, protokół przesłuchania świadka Antoniego Konkela, 31 I 1992 r., t. 1, pp. 59-60; Józef Wiткоwsкi, Dziecko w systemie hitlerowskim, [in:] Człowiek, populacja, środowisko. Prace Dolnoślaskiego Centrum Diagnostyki Medycznej „Dolmed” we Wrocławiu, Wrocław 1988, p. 35; idem, Hitlerowski obóz koncentracyjny dla małoletnich $w$ Łodzi, 




An extract of the record book of the Educational Facility in Wejherowo from the times of the German occupation, the Branch of the Commission for the Prosecution of Crimes against the Polish Nation in Gdańsk, sygn. S 6/00/Zn, investigation in the case of the discrimination of Polish children in the educational facility in Wejherowo during the German occupation, App. No. 1 to the files

Wrocław 1975; Konrad Ciechanowski, Obozy hitlerowskie na Pomorzu w latach 1939-1945 nie podlegajace Inspektoratowi Obozów Koncentracyjnych - stan badań i postulaty badawcze, [in:] Sesje naukowe Okręgowej Komisji Badania Zbrodni przeciwko Narodowi Polskiemu w Gdańsku, Gdańsk 1987, pp. 21-24, archive of OK.Gd., unpublished materials; Henryk PorożyŃsKi, Zakład poprawczy w Chojnicach w latach 1885-1985, Słupsk 1991, p. 70. 
There were various reasons for placing children in the educational facility. The first reason was the punishment for committing minor crimes; some children came from liquidated church orphanages; some children were taken away from their parents who had refused to sign the German People's List. For example, Bronisław Weinchold with his four siblings (eleven-year-old Gertruda, six-year-old Mieczysław, four-year-old Maksymilian and two-year-old Jan) in October 1940 were taken from their house in Torun in the dark of night, when their parents were not at home, and transported to the Wejherowo educational facility. Another example is a charge of the orphanage run by nuns from Chełmno (upon Vistula) Waldemar Bojanowski, who, after the Chełmno orphanage had been dissolved in September 1939, was placed in the local garrison church along with other children and prisoners of war. Next, he was transported to the camp in Potulice, then Stutthof to end up in the Educational Facility in Wejherowo ${ }^{14}$.

Children placed in the Wejherowo facility did not undergo any racial examination that would qualify them as adequate for the Germanization process. According to the data of 31 April 1940 the number of Polish children staying in the facility was 101 boys. However, the witnesses recollect that the number of boys residing in the facility throughout all the period of its functioning could have reached even 300 boys. In the number of 101 charges there were also 31 boys who were later transported to the Camp for Polish Children and Youth in Łodź (Polen Jugendverwahrlager der Sicherheitspolizei in Litzmannstadt) in Przemysłowa Street ${ }^{15}$. The institution was, in fact, the preventive camp of

${ }^{14}$ OK.Gd., sygn. S 6/00/Zn, protokół przesłuchania świadka Bronisława Weincholda, 6 XI 1991, t. 1, pp. 33-34; protokół przesłuchania świadka Waldemara Bojanowskiego, 12 III 1992, t. 1, p. 41.

${ }^{15}$ From 22 February to 23 July 1943 the following boys were transported from the Educational Facility in Wejherowo to the Camp for Polish Children and Youth in Łódź in Przemysłowa Street: Ludwik Kwiatkowski, born 8 September 1929 in the country of Rypin; Waldemar Bojanowski, born 12 May 1930; Czesław Sadłowski, born 20 July 1928; Alojzy Grzuchowski, born 6 Kune 1928 in Grudziądz; Józef Olejniczak, born 19 March 1928 in Lille; Ryszard Rogowski, born 14 May 1927 in Grudziądz; Bernard Radtke, born 8 December 1931; Bronisław Weinchold; Mieczysław Weinchold, born 3 August 1934 in Toruń; Stanisław Szpalerski vel Spolerski, born 4 August 1929 in Metz; Gracjan Ciechanowski, born 10 July 1931 in Świecie; Jerzy Gruzewski, born 16 September 1927 in Bydgoszcz; Franciszek Buszyński, born 22 July 1932; Zdzisław Skopiak, born 28 June 1935; Stanisław Formell, born 18 November 1930; Stanisław Baś, born 26 December 1929 in Serock; Józef Baś, born 25 November 1932 in Serock; Henryk Baś, born 1 August 1934 in Serock; Zbigniew Byszewski, born 24 October 1930 in Toruń; Józef Kowalski, born 30 September 1931 in Grudziądz; Władysław Bedro, born 25 February 1929 in Grudziądz; Stanisław Maja, born 5 February 1931 in Toruń; Tadeusz Banasik, born 8 October 1933 in Toruń; Leon Banasik, born 22 July 1936; Józef Kukso, born 10 November 1928 in the country of Płock; Eugeniusz Zaleśkiewicz, born 17 April 1933; Albert Szklarski, born 17 December 1928; Henryk Polberg, born 1 May 1935 in Bydgoszcz; Zdzisław Piotrowski, born 16 November 1930 
the security police for the Polish youth under maximum security, set up on the strength of an urgent decree of Reichsführera SS Heinrich Himmler of 28 November 1942. Children who were sent there were predominantly the offspring of parents belonging to the resistance movement and actively fighting with the occupying forces. Another group of charges constituted children who had undergone part of their resocialization process in other facilities. From December 1942 to 18 January 1945 about 13,000 Polish children stayed in the Łódź camp, a thousand of whom managed to survive ${ }^{16}$.

Life in the educational facility ran according to some preestablished pattern. The day started at 6 a.m. with some physical exercise and performing the morning toilet. Next, children were given breakfast, normally followed by a morning assembly and classes conducted in the German language. During the morning assembly teachers assigned boys to certain tasks. At noon there started a lunch break, after which boys continued to work until 6 p.m. In the evening another assembly took place, the aim of which was to summarize the day. Until 8 p.m. boys had to be in their beds ${ }^{17}$.

During the stay in the educational facility some boys were temporarily sent to do physical works in farms of the Germans living in the vicinity. The life and work conditions in the farms depended on the attitude of individual farmers. However, most children did not receive any corporal punishment. The work which they had to do was exhausting and lasted from dawn to dusk. Children were normally used to work in the field planting, hoeing and collecting potatoes, weeding, providing fodder to cattle and cleaning. Some children, like e.g. Franciszek Topolski, who worked in the farm of a German Radtke in Żarnowiec, and Jan Józef Wiśniewski employed in the farm of Anton Lang in Letni Dwór, received a small remuneration for their work, which amounted to 4-10 marks a month. Children who did not work in German farms were forced to do physical work in the territory of the adjacent farm, the sewing

in Bydgoszcz; Franciszek Grzekalski, born 27 July 1930 in Bydgoszcz; Władysław Kopydłowski, born 27 August 1931 (Aufnahmebuch Erziehungsanstalt Neustadt, no. 2515-2747).

${ }^{16}$ Józef Wiткоwsкi, Obóz dla dzieci w Łodzi w systemie obozów hitlerowskich, [in:] Dzieci i młodzież w latach drugiej wojny światowej, pp. 222-234; Joanna LeszczyńsKa, Łódzki obóz koncentracyjny dla dzieci, czyli sierociniec Himmlera, Rzeczpospolita, http://www.rp.pl/Plus -Minus/311179958-Lodzki-oboz-koncentracyjny-dla-dzieci-czyli-sierociniec-Himmlera.html (accessed December 27, 2017); Anna Gronczewska, Dramat małych więźniów niemieckiego obozu przy ul. Przemystowej w Łodzi, Dziennik Łódzki, http://archive.is/Ar4cp (accessed December 28, 2017).

${ }^{17}$ OK.Gd., sygn. S 6/00/Zn, protokół przesłuchania świadka Franciszka Topolskiego, 23 III 2001, t. 2, pp. 237-238; protokół przesłuchania świadka Jana Józefa Wiśniewskiego, 23 III 2001, t. 2, pp. 246-247; protokół przesłuchania świadka Zdzisława Pietrowskiego, 24 IV 2001, t. 2, pp. 263-264; protokół przesłuchania świadka Tadeusza Albina Ziółkowskiego, 13 VIII 2001, t. 2, pp. 397-399; protokół przesłuchania świadka Rudolfa Tokarskiego, 15 VI 1990, t. 1, pp. 4-5. 
factory and nearby barracks. In the facility there were special duty hours during which children had to clean, help in the kitchen, help to chop wood. Some children wove wicker baskets (in the building of the barn opposite pavilion no. 2), made doormats and mats, grazed pigs and cows. They had to work six days a week. Children were supervised by teachers, who used corporal punishment to those children who did not manage to meet the quota. They usually beat them with a cane or a whip. Children were not remunerated for their work in the educational facility. Work and study took place in shifts. The day one group of children went to work, another group had classes. Sometimes teachers provided children with the minimum entertainment by showing them e.g. animated films in the German language and organizing outings to go sledging or to the swimming pool.

Boys from the Wejherowo facility remained under the constant supervision of German teachers or local Kashubians. Teachers were exclusively men and in their contacts with children they used only the German language. The head of the facility was a German SA functionary - Engel. Boys remembered him well because he was limp. We know also surnames of other German teachers: Ponke vel Punke, Nacmer vel Natzner, Milewski, Samp, Formella. Teachers always wore civilian clothes. Each teacher was responsible for 10 charges. Children jokingly called them "daddies" [Polish: ojczulki]. Former residents of the institution remember the teachers as severe people who could even beat their charges with a cane, whip or a hand. Antoni Konkel testified: "Sometimes teachers organized the so called military drill and made us stand in two lines and perform the exercise of 'rise and fall' for an hour. When they were tired of speaking, they showed the exercise with their hands. Some children made such a physical effort that their noses started to bleed. Teachers all the time hastened us; they had walking sticks and sometimes used them to beat us. I was also beaten when I did not manage to do all the work on time"18 [trans. Agnieszka Chabros]. His testimony was completed by Jan Bugajski, who said: "Our teacher Necmer mistreated children. Many a time was I a witness of his kicking a child all over the body and in the face; what is more, he poked children with a metal key in various parts of their bodies. I was beaten by Necmer with a broomstick when I was peeling potatoes. He beat me with this broomstick all over my body and my head"19 [trans. A.C.]. Teachers tolerated physical fights among children themselves. They never intervened when a weaker boy was severely beaten. Occasionally Polish children were insulted by the German auxiliary personnel, who called them "Polish pigs". Probably, in the area of the

${ }^{18}$ Ibid., sygn. S 6/00/Zn, protokół przesłuchania świadka Antoniego Konkela, 11 IV 1994, t. 1, p. 82 .

${ }^{19}$ Ibid., pp. 81-83; protokół przesłuchania świadka Jana Bugajskiego, 5 IX 2001, t. 3, pp. $44-448$. 
educational facility one of the rooms constituted a kind of seclusion room. One could be put to the seclusion room for various offences e.g. for working too slowly or verbally assaulting a teacher. All the unsuccessful attempts to escape from facility were punished with the stay in the seclusion room having first received corporal punishment. Boys were closed in the seclusion wearing only underwear for the period of 10 days. Children who had longer hair were shaven. They received only bread to eat and water to drink ${ }^{20}$.

Boys frequently attempted to escape, but they never did it from the territory of the facility. It was easier to escape from the place of work. Examining the entries in "Aufnahmebuch Erziehungsanstalt Neustadt" one may note that some children stayed out of the facility from several days to several months. It is hard to say where they were hidden at that time, what they ate and where they slept. We only know the history of Bolesław Jażdżewski, who worked in the farm of the Reimer family in Leśniów. One day he escaped directly from the field and went on foot to his family home in Kościerzyna. The remaining annotations in the record book constitute brief entries informing about the date of the escape and the date when the boy was brought back to the facility. For instance, Alojzy Zieliński, escaped on 19 April 1940, but he was brought back to the institution on 4 August 1940; Wojciech Wincenty Połczyński, escaped on 21 June 1941, and was brought back to the institution on 28 August 1941; Klemens Miciński, escaped on 21 September 1941, brought back to the centre on 6 Jan 1942; Wacław Wrzesiński, escaped on 6 October 1941, brought back to the centre on 22 December $1943^{21}$.

Polish children, unlike German children, did not have the right to leave the facility. From the windows of their bedrooms they could see young Germans playing joyfully with Gauerziehungsheim. Only on Sundays boys went for a mass service to the Evangelical church. Some boys during their stay in the institution received their First Communion. Two groups of boys received this sacrament: the Catholic charges and the Protestant ones. Families were prohibited to visit them. Even letters sent homes were censored and had to be written in German. Teachers helped younger boys to write letters to their families. However, letters included only laconic information about the health condition and informed that a child did not need anything.

${ }^{20}$ Ibid., protokół przesłuchania świadka Antoniego Konkela, 31 I 1992, t. 1, p. 61; protokół przesłuchania świadka Bronisława Kachniarza, 20 III 2002, t. 3, pp. 496-501; protokół przesłuchania świadka Bernarda Sarnowskiego, 24 VIII 2001, t. 3, pp. 428-429; protokół przesłuchania świadka Bolesława Jeżdżewskiego, 20 VIII 2001, t. 3, pp. 419-420; Aufnahmebuch Erziehungsanstalt Neustadt, no. 1-2223.

${ }^{21}$ Aufnahmebuch Erziehungsanstalt Neustadt, no. 1-2849; OK.Gd., sygn. S 6/00/Zn, protokół przesłuchania świadka Antoniego Konkela, 31 I 1992, t. 1, pp. 59-60. 
Living conditions in the facility were given various opinions. Some children said they were bearable as they got three meals a days. In the first months children on duty brought meals from the kitchen in the adjacent barracks. Later, the facility had its own kitchen and dining room. Firewood was chopped by older boys (e.g. by Antoni Konkel). In the kitchen three cooks, who commuted from Wejherowo, were employed. Former residents of the facility say that for breakfast they were given chicory coffee, two pieces of bread with rutabaga marmalade; for lunch - jacket potatoes with onion sauce and sometimes a small quantity of meat; for dinner they received milk soup with two pieces of bread. Sometimes they were also given biscuits by soldiers living in the adjacent barracks. The buildings where the children stayed were heated, were connected to the sewage system and had current water. In the halls there were loudspeakers transmitting the news in German and German songs. Each charge had his own bed and bedclothes. Next to every bed there was a stool where children could put their clothes. In the rooms there were no wardrobes nor tables. The facility provided blue denim outfits with trousers having white stripes on the side. Clothes corresponded with the season of the year. On Sundays boys wore smart navy-blue clothes. Many charges have bad recollections of having to wear clogs. Those shoes did not have heels, which made walking very inconvenient. Hygienic conditions were sufficient. In the bathrooms soap was always available, and once a week children had to go to the baths in the barracks. Boys were provided with the permanent care of medical doctors and dentists from other institutions. In the territory of Erziehungsanstalt Neustadt there was no infirmary. Children who had to be hospitalized were taken to the military hospital. Bronisław Weinchold spoke very well about the conditions in the facility: "Taking into account the fact what kind of facility it was, the living conditions were very good. I remember us sleeping in the rooms with bunk beds. We slept on pallets and used blankets to keep warm. Bedclothes were very clean and frequently changed. I do not remember how many children slept in one room and how many charges there were altogether in the facility. We received food three times a day. It was good and sufficient. Everyday we had physical exercise in the yard, and when it was cold - in the halls of the facility"22 [trans. A.C.].

Most boys were discharged from the facility in 1943. Some of the boys were transported to the camp for children in Łodź in Przemysłowa Street, to the prison in Radogoszcz (Erweitertes Polizeigefängnis Radegast) and to the educational labour camp Umwandererzenrallager - Thorn [Polish: Szmalcówka lard plant] in Grudziądzka Street in Toruń. Some boys dismissed in that time

${ }^{22}$ OK.Gd., sygn. S 6/00/Zn, protokół przesłuchania świadka Antoniego Konkela, 31 I 1992, t. 1, pp. 59-60; protokół przesłuchania świadka Bronisława Weincholda, 6 XI 1991, t. 1, p. 34. 
had an annotation: "further education in a social care centre". A small number of children were transported close to their family homes and assigned to work in local farms, which happened to Paweł Ball, who was transported from the Wejherowo facility to the vicinities of Drzycim - his family village ${ }^{23}$. In the summer of 1944 Bernard Falkowski was moved to the estate near Grabie in the county of Aleksandrów ${ }^{24}$. Sometimes, if parents had achieved the positive result of the administrative proceedings to join the German People's List, their children were dismissed from the facility and sent back home.

In the files of the facility no deaths were recorded. No killings were recorded, either. During the final evacuation of the facility in January 1945, the personnel with children who had survived set off to Torun. Some boys escaped and headed for their family homes. The rest were placed in social care centres as victims of the war by the Polish authorities. Once their identity had been established, they were sent to their family homes. If they had no parents, they were sent to social care centres and orphanages ${ }^{25}$.

At the present time in the former complex of buildings in Jana Sobieskiego Street in Wejherowo a few institutions are seated. One of them is the Centre for Information and Communication Support and the Commandery of the Naval Forces. Others include: the County Complex of Special Education (at 279 Sobieskiego Street) and the County Centre for the Assistance to Families (at 279A Sobieskiego Street). In the local community of Wejherowo the knowledge about the existence of the psychiatric hospital in the complex of the buildings has been preserved. However, few people are familiar with the fact of the existence of the educational facility there during the occupation period.

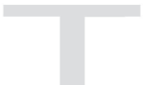

trans. by Agnieszka Chabros

Received 5 April 2017

Received in revised form 3 January 2018

Accepted 25 March 2018

${ }^{23}$ Ibid., sygn. S 6/00/Zn, protokół przesłuchania świadka Pawła Balla, 16 VIII 2001, t. 3, pp. $413-415$.

${ }^{24}$ Ibid., sygn. S 6/00/Zn, protokół przesłuchania świadka Bernarda Falkowskiego, 23 III 2001, t. 2, pp. 240-241.

${ }^{25}$ Oddziałowa Komisja Ścigania Zbrodni przeciwko Narodowi Polskiemu w Łodzi [the Branch of the Commission for the Prosecution of Crimes against the Polish Nation in Lodz], sygn. Ds. 281/67, śledztwo w sprawie zbrodni popełnionych na więźniach i młodzieży obozu przy ul. Przemysłowej w Łodzi, protokół przesłuchania świadka Tadeusza Baś, 14 I 1971, t. 7, pp. 1269-1272; protokół przesłuchania świadka Józefa Baś, 16 I 1971, t. 7, pp. 1273-1274; protokół przesłuchania świadka Henryka Baś, 18 I 1971, t. 7, pp. 1271-1272. 
Dr Monika Tomkiewicz

Institute of National Remembrance

Branch of the Commission for the Prosecution of Crimes against the Polish Nation

e-mail:Monika.Tomkiewicz@ipn.gov.pl

ORCID ID: 0000-0001-5012-3699

\section{Childcare Centre for Polish Boys in Wejherowo DURING THE GERMAN OCCUPATION}

\section{Summary}

Key words: Neustadt, German childcare centres for Polish children, orphanages, territories incorporated into the Third Reich, everyday life in Gdańsk Pomerania during the German occupation

At the beginning of the German occupation in the territories incorporated into the Third Reich all the Polish orphanages and childcare centres became administered by the German authorities. It was in accordance with the incentives included in the book prepared by the Political-Racial Bureau in November 1939 titled The question of the treatment of the population from the former Polish territories from the racial-political point of view, which recommended that racially valuable children should be exempted from resettlements and should be brought up in the Reich in special educational centres which followed the model of the House of Orphans in Potsdam. On 9 September 1939 Wejherowo was taken over by German soldiers from the $207^{\text {th }}$ Infantry Division of Tiedemann, the $32^{\text {nd }}$ Regiment of Grenzwache von Bothmer, the SS Battalion Heimwehr Danzig of Major von Rittberg and the $5^{\text {th }}$ Cavalry Regiment of Diener. The Wejherowo land became part of the Reichsgau Danzig-West Prussia. The occupying forces took over the buildings of the pre-war Centre for Social Care and the Primary School for the Deaf and Mute in Wejherowo, which are now situated at 279 Jana Sobieskiego street (at that time: Adolf-Hitler-Strasse). The buildings served as accommodation for the military units. Buildings no. 2 and no. 4 along with the farm were not utilised. The German administration set up the Educational Centre called "Erziehungsanstalt Neustadt" for Polish and German boys aged 4 to 16 in the dormitory and school buildings. Polish children came from the territories of the former Pomeranian province - Bydgoszcz, Grudziądz, Toruń, Gdynia, Starogard Gdański and Kartuzy. The number of children of Polish nationality who stayed in the educational centre in Wejherowo amounted to 101 boys 9 according to the data of 31 April 1940). During their stay in the centre in Wejherowo boys were supervised by German teachers or local Kashubians. From time to time children were sent to nearby farms to help in agricultural works. In 1943 the decision was made to liquidate the centre gradually. Thirtyone boys were transported to the camp for children in Łódź in Przemysłowa street. During the evacuation of the centre some children escaped to their family homes. The remaining children were placed by the Polish authorities in childcare centres as vic- 
tims of the war. Once their identity had been established, they were sent to their family homes. Orphans were placed in orphanages and childcare centres.

\section{Die ERZiehungsanstalt FÜR POLNISCHE JUNGeN in Neustadt in Westpreussen in Der Zeit der deutschen Besatzung}

\section{Zusammenfassung}

Schlüsselwörter: Neustadt, deutsche Erziehungseinrichtungen für polnische Kinder, Waisenhäuser, vom Dritten Reich annektierte Gebiete, Alltagsleben im Danziger Pommern während der deutschen Besatzung

$\mathrm{Zu}$ Beginn der deutschen Besatzung wurden auf den vom Dritten Reich annektierten Gebieten alle polnischen Waisenhäuser und Erziehungseinrichtungen unter deutsche Verwaltung gestellt. Dies entsprach den Richtlinien in einem Papier des Rassepolitischen Amtes aus dem November 1939 mit dem Titel „Die Behandlung der Bevölkerung in ehemaligen polnischen Gebieten aus rassepolitischer Sicht“, in der empfohlen wurde, rassisch wertvolle Kinder von Umsiedlungen auszunehmen. Sie sollten auf dem Gebiet des Reichs in entsprechenden Erziehungsanstalten erzogen werden, die sich am Vorbild des Waisenhauses in Potsdam orientierten. Am 9. September 1939 wurde Neustadt von deutschen Soldaten der 207. Infanteriedivision unter Carl von Tiedemann, dem 32. Grenzwach-Regiment unter Freiherr von Bothmer, dem SS-Bataillon Heimwehr Danzig unter Major von Rittberg und dem 5. Kavallerie-Regiment unter Oberstleutnant Diener eingenommen. Das Gebiet von Neustadt wurde dem Reichsgau Danzig-Westpreußen einverleibt. Die Besatzungsbehörden übernahmen die Gebäude eines Pflegeheims und einer Grundschule für Taubstumme in Neustadt, die heute in der ul. Jana Sobieskiego 279 (damals Adolf-Hitler-Straße) liegen, und bestimmten sie für die Einquartierung von Armeeabteilungen. Unbewirtschaftet blieben die Häuser mit den Nummern 2 und 4 sowie eine Landwirtschaft. Im Internat und in den Schulgebäuden eröffnete die deutsche Verwaltung eine Erziehungseinrichtung mit dem Namen „Erziehungsanstalt Neustadt“ für polnische und deutsche Jungen im Alter von 4 bis 16 Jahren. Die polnischen Kinder kamen aus dem Gebiet der ehemaligen Wojewodschaft Pommern, d. h. aus Bromberg, Graudenz, Thorn, Gdingen, Stargard, Danzig und Karthaus. Die Zahl der Kinder polnischer Nationalität in der Anstalt in Neustadt betrug nach Angaben vom 31. April 1940101 Jungen. Während des Aufenthalts in der Anstalt in Neustadt standen die Jungen unter ständiger Aufsicht von deutschen Erziehern oder örtlichen Kaschuben. Manchmal erhielten die Kinder Urlaub und arbeiteten dann in nahegelegenen Landwirtschaftsbetrieben. 1943 wurde entschieden die Anstalt schrittweise aufzulösen. 31 Jungen wurden in ein Lager für Kinder in Lodz in der ul. Przemysłowa gebracht. Im Verlauf der Evakuierung der Anstalt flohen einige Kinder und gelangten hauptsächlich in ihre Elternhäuser. Der übrige Teil wurde nach dem Durchgang der Front von den polnischen Behörden als Kriegsopfer in Betreuungsanstalten untergebracht, von wo sie nach Feststellung ihrer 
Identität in ihre Elternhäuser gebracht wurden bzw. im Fall von Waisen in Betreuungsanstalten und Kinderheime.

\section{BIBLIOGRAPHY}

Borzyszkowski, Józef, ed. Historia Wejherowa. Wejherowo: Muzeum Piśmiennictwa i Muzyki Kaszubsko-Pomorskiej, 1998.

Ciechanowski, Konrad. Obozy hitlerowskie na Pomorzu w latach 1939-1945 nie podlegające Inspektoratowi Obozów Koncentracyjnych - stan badań i postulaty badawcze. Gdańsk: Sesje naukowe Okręgowej Komisji Badania Zbrodni przeciwko Narodowi Polskiemu w Gdańsku, unpublished, 1987.

Ciechanowski, Konrad. "Okupacyjne losy polskich dzieci i młodzieży na Pomorzu Gdańskim.” In Dzieci i młodzież w latach drugiej wojny światowej, edited by Czesław Pilichowski. Warszawa: Państwowe Wydawnictwo Naukowe, 1982.

Daniluk, Jan. SS w Gdańsku. Gdańsk: Instytut Pamięci Narodowej, 2013.

Gronczewska, Anna. "Dramat małych więźniów niemieckiego obozu przy ul. Przemysłowej w Łodzi.” Dziennik Łódzki. Access December 28, 2017. http://archive. is/Ar4cp.

Jastrzębski, Włodzimierz and Sziling Jan. Okupacja hitlerowska na Pomorzu Gdańskim w latach 1939-1945. Gdańsk: Wydawnictwo Morskie, 1979.

Historia Ośrodka Szkolno-Wychowawczego nr 2 dla Głuchych im. J. Siestrzńskiego $w$ Wejherowie. Wejherowo, 1991.

Hrabar, Roman Z. Hitlerowski rabunek dzieci polskich. Uprowadzanie i germanizowanie dzieci polskich w latach 1939-1945, Katowice: Śląsk, 1960.

Hrabar, Roman Z. Janczarowie XX wieku. Katowice: Sląsk, 1983.

Kaczmarek, Ryszard. "Niemiecka polityka narodowościowa na Górnym Śląsku (1939-1945).” Pamięć i Sprawiedliwość 2 (6) (2004): 115-138.

Kotewicz, Józef. "Pięćdziesięciolecie ośrodka szkolno-wychowawczego nr 2 dla głuchych w Wejherowie". In Biblioteka Muzeum Piśmiennictwa i Muzyki KaszubskoPomorskiej w Wejherowie, 67, Wejherowo: Muzeum Piśmiennictwa i Muzyki Kaszubsko-Pomorskiej w Wejherowie 1983.

Krauss, P. Damals. Heimwehr Danzig. Erinnerungen und Begegnungen. Cobburg, 1982.

Leszczyńska, Joanna. "Eódzki obóz koncentracyjny dla dzieci, czyli sierociniec Himmlera." Rzeczpospolita. Access December 27, 2017. http://www.rp.pl/Plus-Minus/ 311179958-Lodzki-oboz-koncentracyjny-dla-dzieci-czyli-sierociniec-Himmlera. html.

Leszczyński, Edward. Sonderbehandlung. Zbrodnia na polskich dzieciach. Wrocław: Wydawnictwo „Wektory”, 2014.

Michaelis, Rolf. SS-Heimwehr Danzig 1939. Warszawa: Militaria, 2003.

Milczewski, Zygmunt. Wejherowo i powiat morski wrzesień 1939 - maj 1945 (kronika). Gdańsk, 1991. 
Osowicka, Regina. "Matki mdlały z rozpaczy, sieroty z głodu jadły śnieg. Odyseja „polskich dzieci syberyjskich” przez Japonię do Wejherowa." Dziennik Bałtycki (1994): 7.

Porożyński, Henryk. Zakład Poprawczy w Chojnicach w latach 1885-1985. Słupsk: Wyższa Szkoła Pedagogiczna, 1991.

Pospieszalski, Karol Marian. Niemiecka Lista Narodowa w „Kraju Warty” (Documenta Occupationis Teutonicae, t. 4). Poznań: Instytut Zachodni, 1949.

Witkowski, Józef. “Dziecko w systemie hitlerowskim.” In Człowiek, populacja, środowisko. Prace Dolnośląkiego Centrum Diagnostyki Medycznej „Dolmed” we Wrocławiu. Wrocław, 1988.

Witkowski, Józef. Hitlerowski obóz koncentracyjny dla małoletnich w Łodzi. Wrocław: Zakład Narodowy im. Ossolińskich, 1975.

Witkowski, Józef. “Obóz dla dzieci w Łodzi w systemie obozów hitlerowskich.” In Dzieci i młodzież w latach drugiej wojny światowej, ed. Czesław Pilichowski. Warszawa: Państwowe Wydawnictwo Naukowe, 1982.

Wnuk, Józef, Helena Radomska-Strzemecka. Dzieci polskie oskarżaja 1939-1945. Warszawa: Pax, 1961.

Ziemia wejherowska. Gdańsk: Wydawnictwo Morskie, 1980.

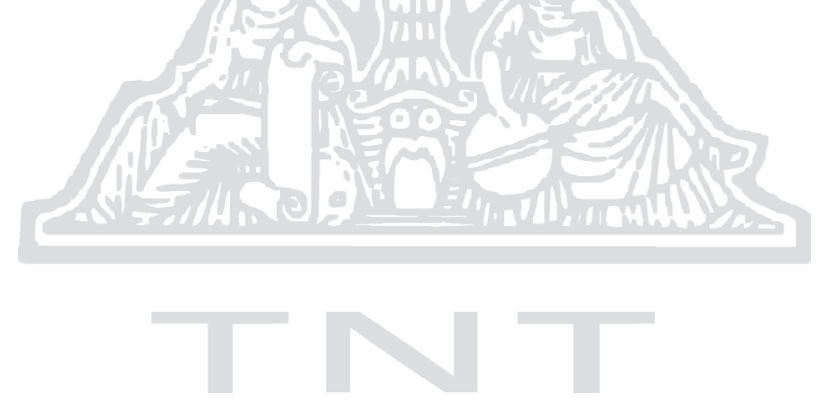

